\title{
Aquatic Gardens, Not Aquatic Pests: How to Practice Responsible Water Gardening
}

PAMELA M. GEISEL, Academic Coordinator, UC Statewide Master Gardener Programs; DONNA C. SEAVER, Program Representative, UC Statewide Master Gardener Program; and HOLLY CROSSON, Department of Environmental Science and Policy, University of California, Davis

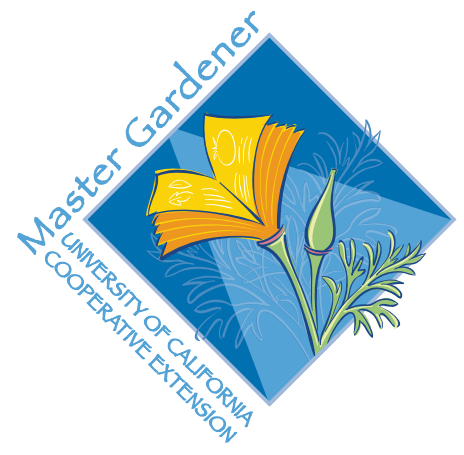

Water gardening is popular in California, and many Californians enjoy growing aquatic plants in backyard ponds or home aquaria. Most of the plants used in gardens and landscaping do not invade or harm wildlands and waterways. But a few vigorous non-native species can, and do, escape from cultivation into natural landscapes where they cause a variety of ecological problems. These introductions

occur when people dump unwanted plants into local storm drains, streams, or ponds, or when floods or wildlife transport them. Once released, invasive aquatic plants cause serious ecological and economic problems for California's water bodies. They can

- form dense stands along the shore or thick mats in open water. (Sometimes so much of the water surface is covered that migrating water birds cannot land.)

- crowd out native plants while providing little benefit to wildlife

- reduce light and oxygen levels underwater, killing fish and other aquatic life

- clog intake valves of irrigation systems and power plants

- reduce access to waterways for recreational and commercial boats

- use significantly more water than native species. For example, a 10,000-acre infestation of giant reed (Arundo donax) on the Santa Ana River in Orange County is estimated to use 57,000 acre-feet more water per year than native vegetation. (For equivalents between U.S. and metric systems of measurement, a conversion table is provided at the end of this publication.)

Because so many waterways are interconnected, one plant dumped in a local storm drain can travel for miles. Federal, state, and local agencies spend millions of dollars each year to remove invasive aquatic plants. Preventing their spread costs much less than removing the plants once they have escaped. 


\section{How You Can Help}

It is vital to follow safe gardening practices:

- Build your water garden away from natural waterways.

- Plant non-invasive alternatives.

- Become familiar with the plants discussed in the brochure Don't Plant a Pest! It includes photos of invasive species and suggests alternative plants. Ask your local Master Gardener for a copy or contact the California Invasive Plant Council (510-843-3902 or http://www.cal-ipc.org). Consult your local aquatic gardening specialist to determine which plants are best for your setting.

- Grow plants in containers to reduce the likelihood that they will spread. This also simplifies pond maintenance.

- Dispose of unwanted pond plants by composting or sealing in plastic bags and placing in a trash container.

- Prevent introductions-do not purchase plants restricted by California law, especially when shopping on the Internet.

\section{Avoid Using InVASIVE SPECIES}

To lessen the risk of environmental hazards, do not plant the following:

Brazilian Waterweed, Anacharis (Egeria densa) Infests 7,000 acres in the Sacramento-San Joaquin Delta. Aggressively invades natural waterways, forming dense mats that impede water flow.

\section{Eurasian Watermilfoil (Myriophyllum spicatum)}

The most widespread submerged invasive aquatic plant in California and a serious problem in Lake Tahoe. Stems break easily, starting new infestations when spread by boats or birds.

\section{Giant Reed (Arundo donax)}

A serious problem along rivers and streams. Dense growth damages habitat while creating a fire and flood hazard. Variegated varieties may also be problematic and are not recommended.

\section{Giant Salvinia (Salvinia molesta)}

Illegal to sell in the United States. Floating mats up to 3 feet thick reduce light and dissolved oxygen in the water so that few living things can survive. Common salvinia (Salvinia minima) may be sold, but species are difficult to tell apart.

\section{Hydrilla (Hydrilla verticillata)}

Illegal to sell or possess in California. Has arrived in California mixed with shipments of water lilies and as a mislabeled aquarium plant. Fragments quickly start new colonies.

\section{Parrotfeather (Myriophyllum aquaticum)}

Forms dense mats that impede water flow. Stems are brittle and break easily. Spread by boats or migrating water birds. Occasional problem in California with great potential to spread.

\section{Purple Loosestrife (Lythrum salicaria)}

Invades stream banks and wetlands throughout the United States. One plant can produce over two million seeds. Has the potential to infest rice fields.

\section{Uruguayan Water-Primrose or Creeping} Water-Primrose (Ludwigia hexapetala, $L$. uruguayensis, L. peploides)

Crowds out native plants and reduces water quality. Dense mats slow water movement and may create habitat for mosquito larvae, which can carry West Nile virus. Although native Ludwigia species exist, do not collect them from the wild.

\section{Water Hyacinth (Eichhornia crassipes)}

Reputed to be the fastest-growing plant in the world. Can double in size in a week during hot weather. Forms dense mats that slow water flow. Seeds can live up to 20 years.

\section{Yellowflag Iris (Iris pseudacorus)}

Forms colonies along stream and pond margins.

Listed as a noxious weed in Nevada, and expanding in Pacific Northwest. Increasingly common in California, and a serious problem in regions with similar climates. 


\section{Do not plant}

FLOATING OR ROOTED EMERGENT

- giant salvinia (Salvinia molesta)

- water hyacinth (Eichhornia crassipes)

\section{Try these non-invasive alternatives instead}

- Cape pondweed (Aponogeton distachyon)

- Pacific fairy fern (Azolla filiculoides)

- yellow pond lily (Nuphar polysepalum)

\section{SUBMERGED}

- Eurasian watermilfoil (Myriophyllum spicatum)

- hydrilla (Hydrilla verticillata)

- Brazilian waterweed, anacharis (Egeria densa)
- coontail or hornwort (Ceratophyllum demersum)

Note: There are few safe alternatives to submerged plants.

These plants spread freely, especially those that are not rooted.

\section{POND MARGIN OR BOG}

- giant reed (Arundo donax)

- purple loosestrife (Lythrum salicaria)

- parrotfeather (Myriophyllum aquaticum)

- yellowflag iris (Iris pseudacorus)
- Cape thatching reed (Chondropetalum tectorum)

- clumping bamboos (Bambusa multiplex 'Alphonso-Karr,' 'Golden Goddess')

- redtwig dogwood (Cornus sericea), yellowtwig dogwood (C. s. 'Flaviramea')

- common waterplantain (Alisma plantago-aquatica)

- common yellow monkey flower (Mimulus guttatus)

- Japanese iris (Iris ensata 'Variegata' and cultivars)

- laevigata iris (Iris laevigata and cultivars)

- mulefat (Baccharis salicifolia)

- Siberian iris (Iris sibirica 'Butter-\&-Sugar')

- soft rush (Juncus effusus)

- western blueflag iris (Iris missouriensis, l. longipetala)

- arrowheads (Sagittaria latifolia, S. montevidensis)

- lobelias (Lobelia cardinalis, L. fulgens, L. siphilica)

- pickerelweed (Pontederia cordata)

- Wilson's ligularia (Ligularia wilsoniana)
Please contact your local Master Gardener for more information or go online to http://camastergardeners. ucdavis.edu.

We gratefully acknowledge support for this project from the Elvenia J. Slosson Research Endowment for Ornamental Horticulture and the Alexander and Elizabeth Swantz Watershed Science Endowment. Content and photos used in this publication were excerpted, with permission, from Don't Plant a Pest: Suggested Alternatives for Invasive Aquatic Plants in California by the California Invasive Plant Council. Contributors: Pat Akers, California Department of Food and Agriculture; Lars Anderson, USDA ARS
Western Regional Research Center; Dave Allen, Shore Road Nursery (Port Angeles, WA); Carl Bell, UC Cooperative Extension (San Diego); Neil Bobo, Pond Revival (Berkeley); Holly Crosson, UC Davis Arboretum and UC Sea Grant Extension Program; Joseph DiTomaso, UC Davis Weed Research and Information Center; Jan Enderle, Orchard Nursery and Florist (Lafayette); Jeff Hart, Hartland Nursery (Walnut Grove); Randy McDonald, McDonald's Aquatic Nurseries (Reseda); Mary Pfeiffer, Shasta County Department of Agriculture; Don Shor, Redwood Barn Nursery (Davis); Rick Storre, Freshwater Farms (Eureka). Poster design: Will Suckow Illustration. 


\section{Resources Accessible ONLINE}

\section{Web Sites}

California Master Gardeners http://camastergardeners.ucdavis.edu/

California Department of Fish and Game (CDFG), Invasive Species Program http://www.dfg.ca.gov/invasives

California Division of Food and Agriculture (CDFA), Division of Plant Health and Pest Prevention Services, Integrated Pest Control Branch http://www.cdfa.ca.gov/phpps/ipc/

California Invasive Plant Council (Cal-IPC) http://www.cal-ipc.org/

Center for Aquatic and Invasive Plants, Institute for Food and Agricultural Sciences, University of Florida http://aquat1.ifas.ufl.edu

Habitattitude http://habitattitude.net/

PlantRight - California Horticultural Invasives Prevention Partnership (Cal-HIP) http://www.plantright.org/index.php

Reducing the Introduction and Distribution of Non-Native Aquatic Invasive Species Through Outreach and Education (RIDNIS)

http://www.ridnis.ucdavis.edu/

The Nature Conservancy's Global Invasive Species Team

http://tncweeds.ucdavis.edu/

USDA National Invasive Species Information Center (NISIC)

http://www.invasivespeciesinfo.gov/aquatics/ main.shtml

U.S. Geological Survey, Nonindigenous Aquatic Species http://nas.er.usgs.gov/taxgroup/plants/ default.asp
Washington State Department of Ecology Aquatic Plant Identification Manual http://www.ecy.wa.gov/programs/wq/ plants/plantid2/index.html

Western Aquatic Plant Management Society http://www.wapms.org

\section{Publications/Brochures}

Aquatic and Riparian Weeds of the West

ANR Publication 3421 http://anrcatalog.ucdavis.edu/InOrder/ Shop/ItemDetails.asp?ItemNo=3421

Aquatic Nuisance Species Identification Cards ANR Publication SG010 http://anrcatalog.ucdavis.edu/InOrder/ Shop/ItemDetails.asp?ItemNo=SG010

Catalog of Aquatic Invasive Species http://www.clr.pdx.edu/projects/edoutreach/

Don't Plant a Pest: Suggested Alternatives for Invasive Aquatic Plants in California http://www.cal-ipc.org

Do Your Part To Protect Our Waterways. Do Not Release Live Aquatic Organisms! http://www.ridnis.ucdavis.edu/Docs/ERP02-P37PosterEng.pdf

PlantRight Brochure http://www.plantright.org/materials/pdfs/ PlantRightBrochure.pdf

Recommended Voluntary Guidelines Aquatic Horticulture Industry http://www.ridnis.ucdavis.edu/NovWrkshp/ FnlIndGlns.pdf

\section{In Spanish}

\section{Invasores de la bahia}

http://www.ridnis.ucdavis.edu/Docs/ final\%20Spanish\%20brochure.pdf

\section{In Chinese}

Do Your Part To Protect Our Waterways. Do Not Release Live Aquatic Organisms! http://www.ridnis.ucdavis.edu/Docs/ERP02-P37PosterChnse.pdf 


\section{English Metric Conversions}

\begin{tabular}{|l|c|c|l|}
\hline English & $\begin{array}{c}\text { Conversion factor for } \\
\text { English to metric }\end{array}$ & $\begin{array}{c}\text { Conversion factor for metric } \\
\text { to English }\end{array}$ & Metric \\
\hline inch (in) & 2.54 & 0.394 & centimeter $(\mathrm{cm})$ \\
\hline foot (ft) & 0.3048 & 3.28 & meter $(\mathrm{m})$ \\
\hline acre (ac) & 0.4047 & 2.47 & hectare (ha) \\
acre-foot (ac-ft) & 1,233 & 0.000811 & cubic meter $\left(\mathrm{m}^{3}\right)$
\end{tabular}

\section{FOR FURTHER INFORMATION}

To order or obtain ANR publications and other products, visit the ANR Communication Services online catalog at http://anrcatalog.ucdavis.edu or phone 1-800-994-8849. You can also place orders by mail or FAX, or request a printed catalog of our products from

University of California

Agriculture and Natural Resources

Communication Services

6701 San Pablo Avenue, 2nd Floor

Oakland, California 94608-1239

Telephone 1-800-994-8849 or 510-642-2431

FAX 510-643-5470

E-mail: danrcs@ucdavis.edu

(C)2009 The Regents of the University of California

Agriculture and Natural Resources

All rights reserved.

No part of this publication may be reproduced, stored in a retrieval system, or transmitted, in any form or by any means, electronic, mechanical, photocopying, recording, or otherwise, without the written permission of the publisher and the authors.

\section{Publication 8369}

ISBN-13: 978-1-60107-641-0

The University of California prohibits discrimination or harassment of any person on the basis of race, color, national origin, religion, sex, gender identity, pregnancy (including childbirth, and medical conditions related to pregnancy or childbirth), physical or mental disability, medical condition (cancer-related or genetic characteristics), ancestry, marital status, age, sexual orientation, citizenship, or service in the uniformed services (as defined by the Uniformed Services Employment and Reemployment Rights Act of 1994: service in the uniformed services includes membership, application for membership, performance of service, application for service, or obligation for service in the uniformed services) in any of its programs or activities.
University policy also prohibits reprisal or retaliation against any person in any of its programs or activities for making a complaint of discrimination or sexual harassment or for using or participating in the investigation or resolution process of any such complaint.

University policy is intended to be consistent with the provisions of applicable State and Federal laws.

Inquiries regarding the University's nondiscrimination policies may be directed to the Affirmative Action/Equal Opportunity Director, University of California, Agriculture and Natural Resources, 1111 Franklin Street, $6^{\text {th }}$ Floor, Oakland, CA 94607, (510) 987-0096. For information about ordering this publication, telephone 1-800-994-8849. For assistance in downloading this publication, telephone 530-754-3927.

To simplify information, trade names of products have been used. No endorsement of named or illustrated products is intended, nor is criticism implied of similar products that are not mentioned or illustrated.

An electronic copy of this publication can be found at the ANR Communication Services catalog Web site, http://anrcatalog. ucdavis.edu.

\section{uc}

This publication has been anonymously peer reviewed for technical accuracy by University of REVIEWED California scientists and other qualified professionals. This review process was managed by the ANR Associate Editor for Pest Management-Urban.

wb-09/09-LR/CR 


\section{Ask a UC Master Gardener}

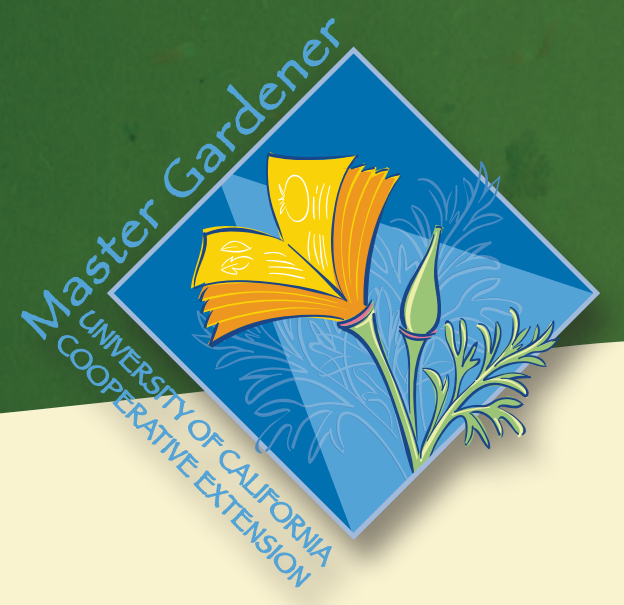

\section{Aquatic Gardens, Not Aquatic}

Pests: How to Practice

\section{Responsible Water Gardening}

\section{Invasive aquatic plants have escaped from} water gardens into natural waterways,

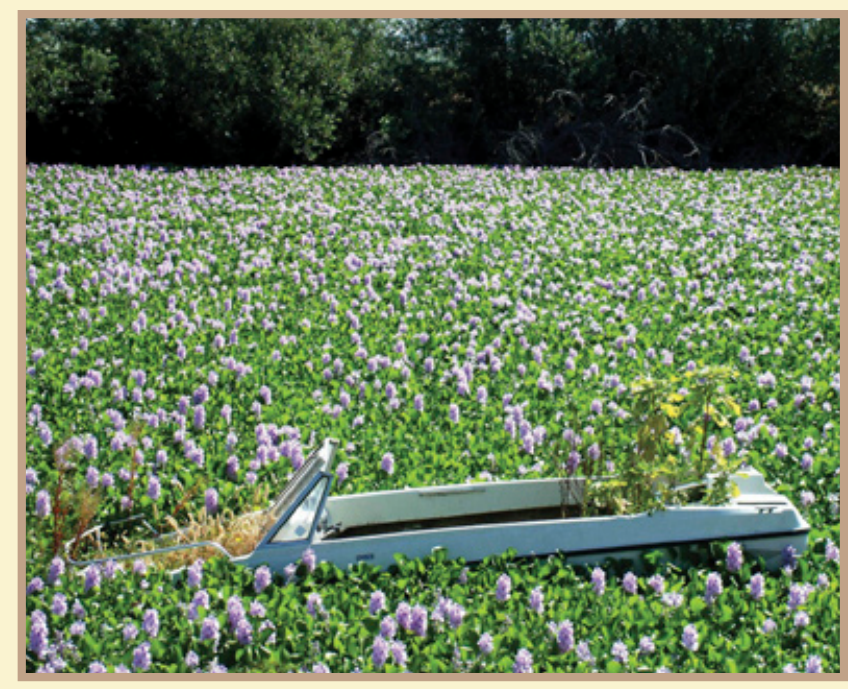

Water hyacinth surrounding boat. Photo: Bob Case harming native plants, fish, and other aquatic life.

To prevent these introductions, do not dump plants from your water garden or aquarium into local storm drains, streams, or ponds.

Please contact your local Master Gardener for more information (http://camastergardeners.ucdavis.edu).

We gratefully acknowledge support for this project from the Elvenia J. Slosson Research Endowment for Ornamental Horticulture and the Alexander and Elizabeth Swantz Watershed Science Endowment.

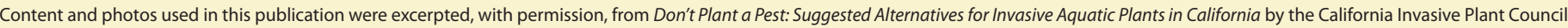
Contributors: Pat Akers, California Department of Food and Agriculture; Lars Anderson, USDA ARS Western Regional Research Center; Dave Allen, Shore Road Nursery (Port Angeles, WA); Carl Bell, UC Cooperative Extension (San Diego); Neil Bobo, Pond Revival (Berkeley); Holly Crosson, UC Davis Arboretum and UC Sea Grant Extension Program; Joseph DiTomaso, UC Davis Weed Research and Information Center; Jan Enderle, Orchard Nursery and Florist (Lafayette); Jeff Hart, Hartland Nursery (Walnut Grove); Randy McDonal
Pfeiffer, Shasta County Department of Agriculture; Don Shor, Redwood Barn Nursery (Davis); Rick Storre, Freshwater Farms (Eureka).

Project management: Pamela M. Geisel and Donna C. Seaver, UC Statewide Master Gardener Program; and Holly Crosson, UC Davis Department of Environmental Science and Policy. Poster design: Will Suckow Illustration. 


\section{Aquatic Gardens, Not Aquatic Pests: How To Practice Responsible Water Gardening}

\section{How you can help:}

- Prevent introductions - DO NOT RELEASE or purchase invasive plants, such as:

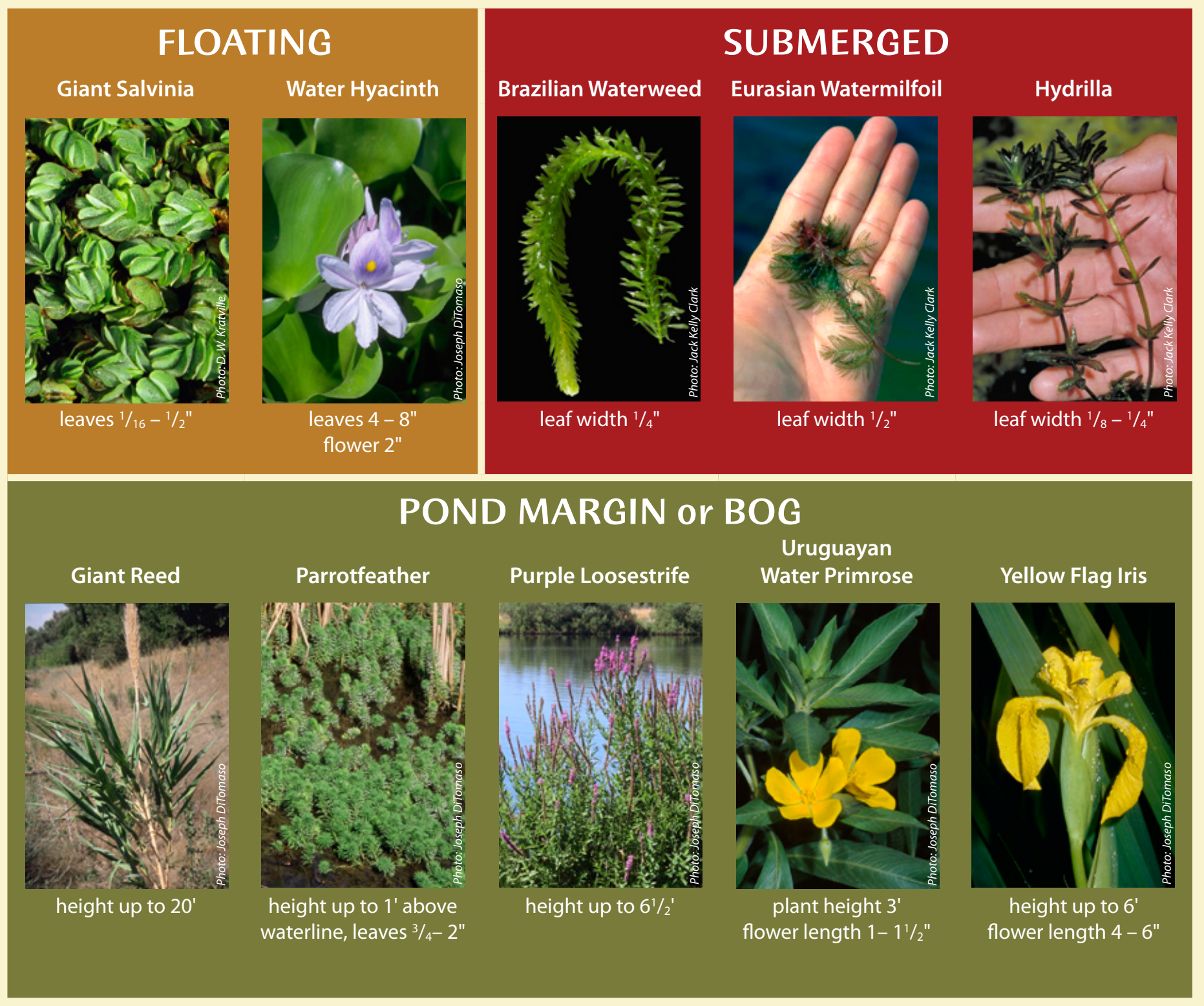




\section{Aquatic Gardens, Not Aquatic Pests:}

\section{How To Practice Responsible Water Gardening}

How you can help:

- Grow plants in containers to reduce the chance of spread. Even native plants can grow vigorously in your pond.

- Dispose of unwanted pond plants by composting away from water bodies or sealing in plastic bags and placing in a trash container.

- Build your water garden away from natural waterways.

- Plant non-invasive alternatives, such as:
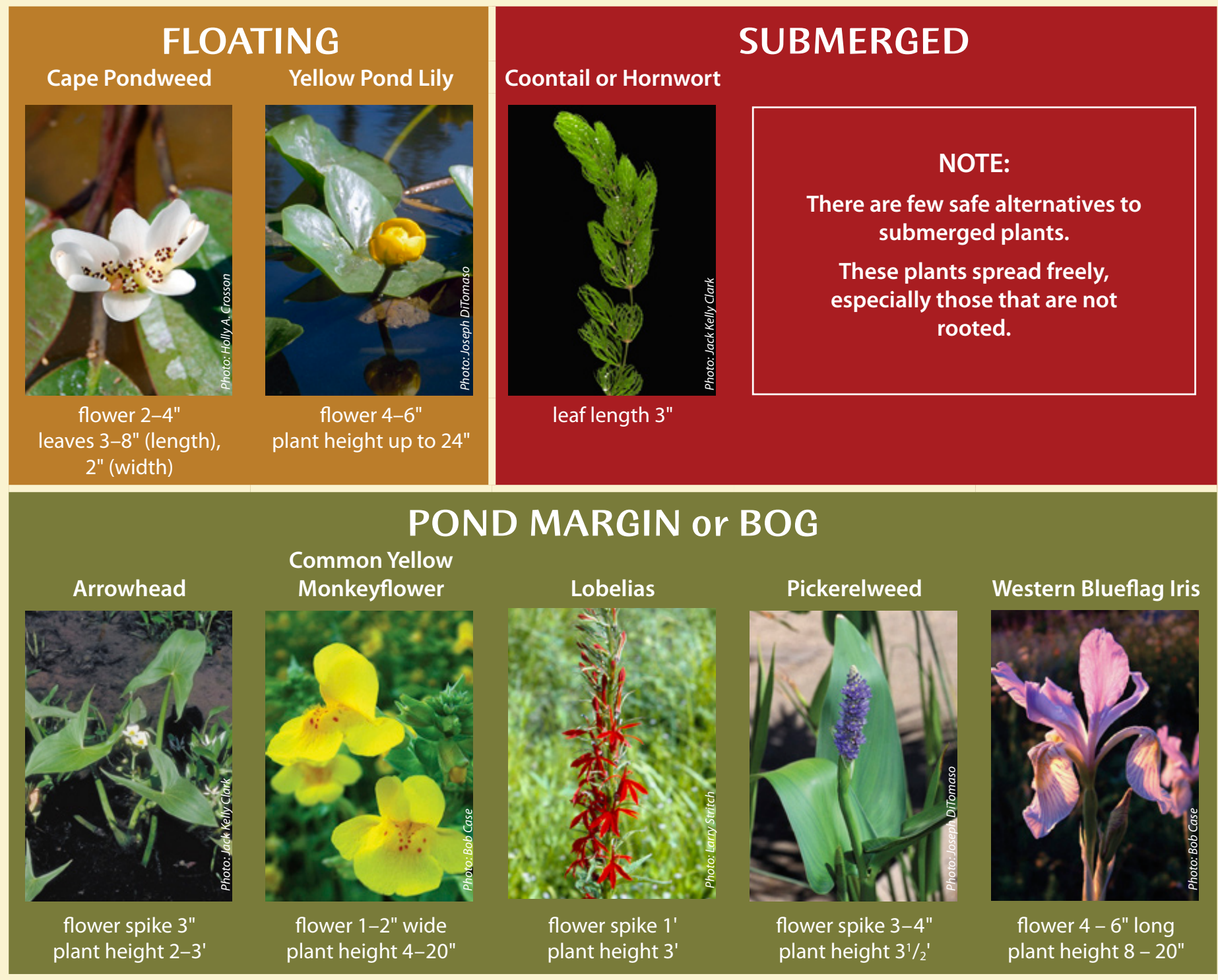